\title{
IN FORTHCOMING ISSUES
}

Rimvydas Šilbajoris, "Kristijonas Donelaitis: A Lithuanian Classic"

Gary Marker, "Russia and the 'Printing Revolution': Notes and Observations"

John-Paul Himka, "Young Radicals and Independent Statehood: The Idea of a Ukrainian Nation-State, 1890-1895"

David Lowe, "Vladimir Odoevskii as Opera Critic"

Thomas C. Owen, "A New Approach to the KurbskiiGroznyi Problem"

Patricia K. Grimsted, "Recent Publications on Archives and Manuscript Collections in the Soviet Union - A Selected Survey"

Discussion: Daniel Brower, "Labor Violence in Russia in the Late Nineteenth Century." Comments by Robert Johnson, Diane Koenker, and Ronald Grigor Suny

\section{TO THOSE WISHING TO SUBMIT MANUSCRIPTS}

Manuscripts for consideration should be submitted in four, doublespaced copies. Footnotes should be double-spaced and placed at the end of the manuscript. Manuscripts are sent to referees anonymously and should be prepared accordingly. Library of Congress transliteration should be used. In general, articles should not exceed twenty-five pages. Manuscripts will not be returned unless postage is provided.

The policy of the Slavic Review is not to consider materials that have been published or that are being considered for publication elsewhere.

Publication of articles in the Slavic Review is ordinarily limited to those submitted by members of the AAASS. Nonmembers wishing to submit manuscripts are asked to request a membership application. 


\section{New and Significant Titles From Allen \& Unwin}

\section{EDUCATION IN THE SOVIET UNION \\ Policies and Institutions Since Stalin Mervyn Matthews}

An up-to-date and comprehensive survey of the successes and tailures of education and training in the Khrushchev and Brezhnev years based on an objective assessment of the accessibility of the main types of institutions, content of courses, and Soviet attempts to amalgamate their education system to their perceived economic and social needs.

Cloth- $\$ 28.50$

July 1982

\section{THE END OF SOCIAL INEQUALITY?}

Class, Status and Power Under State Socialism

David Lane

The best available analysis of the true role of class stratification in state socialist societies and in particular the Soviet Union. Professor Lane's discussion ranges over such aspects as income and education differentials, the rise of white-collar occupations, the position of women and ethnic groups, and social mobility.

Cloth-\$27.50 Paper-\$8.95

\section{SOVIET RISK-TAKING AND CRISIS BEHAVIOR}

\section{A Theoretical and Empirical Analysis}

Hannes Adomeit

Foreword by Marshall Shulman

Detailed examination of the two Berlin crises forms the empirical background against which comparisons are made with the role of the Soviets in other crises - in Cuba, the Middle East, in Vietnam and in Afghanistan - as well as with patterns of Soviet intervention in Eastern Europe.

Cloth- $\$ 47.50$

Studies of the Russian institute, Columbia University

\section{RUSSIA AT THE CROSSROADS: THE 26th CONGRESS OF THE CPSU}

Seweryn Bialer and Thane Gustatson, Eds.

Derived from the Rand-Columbia conference which used the Party Congress as a focus for schotarly analysis of the severe domestic and international dilemmas confronting the Soviet Union in the 1980's and the capacity of an aging Soviet leadership to respond to them.

Cloth- $\$ 28.50$

Published under the auspices of the Rand Corporation and the Russian institute, Columbia University

\section{THE ECONOMICS OF SOCIALISM, 4th edition}

\section{Principles Governing the Operation of the Centrally Planned Economies Under the New System} Jozef Wilczynski

A completely revised concise exposition of theoretical and practical elements of the operation of the planned economies in the USSR, Eastern Europe, and other Socialist countries. Special attention is given to economic reforms and recent developments.

Paper-\$10.95

\section{SOLDIERS, PEASANTS, AND BUREAUCRATS}

Civil-Military Relations in Communist and Modernizing Societies

Roman Kolkowicz and Andrzej Korbonski, Eds.

A cross-disciplinary examination of the main theoretical, methodological, and empirical approaches to the study of civil-military relations in the Middle East, in the socialist countries of Eastern Europe, and China.

Cloth- $\$ 37.50$

\section{THE MIDDLE EAST AND THE WESTERN ALLIANCE}

\section{Steven L. Spiegel, Ed.}

Internationally recognized experts bring together different and distinctive perspectives on the Arab Israeli dispute, the dynamics of the energy crisis, alliance unity and the role of the Soviet Union, and the effect of growing Middle East instability on the interests of individual allied countries.

Cloth- $\$ 28.50$

Center for International and Strategic Affairs, University of California, Los Angeles

Allen \& Unwin, 9 Winchester Terrace, Winchester, Massachusetts 01890 